\title{
BIOETHANOL PRODUCTION FROM SUGAR BEET THICK JUICE BY SACCHAROMYCES CEREVISIAE IMMOBILIZED IN ALGINATE-MAIZE STEM GROUND TISSUE BEADS
}

\section{PROIZVODNJA BIOETANOLA IZ GUSTOG SOKA ŠEĆERNE REPE POMOĆU ĆELIJA SACCHAROMYCES CEREVISIAE IMOBILISANIH U KUGLICAMA OD ALGINATA I SREDIŠNJEG DELA STABLA KUKURUZA}

\author{
Vesna M. VUČUROVIĆ*, Vladimir S. PUŠKAŠ $\check{S}^{*}$ Uroš D. MILJIĆ*, Jovana J. ĐURAN",Jelena S. FILIPOVIĆ ${ }^{* *}$ \\ ${ }^{*}$ Univerzitet u Novom Sadu, Tehnološk ifakultet, Bulevar cara Lazara 1, 21000 Novi Sad, Srbija \\ ** Univerzitet u Novom Sadu, Naučni institut za prehrambene tehnologije, Bulevar cara Lazara 1, 21000 Novi Sad, Srbija \\ e-mail:vvvesna@uns.ac.rs
}

\begin{abstract}
Ethanol produced by alcoholic fermentation from renewable sources, referred to as bioethanol, is widely used as an environmentally friendly and renewable energy source, as well as a chemical in various industries such as the medical, food and feed, pharmaceutical and chemical industries. This paper investigates the bioethanol production from sugar beet thick juice by immobilized Saccharomyces cerevisiae cells in calcium alginate beads and in a new matrix in the form of combined alginate-maize stem ground tissue beads. Higher values of fermentation parameters were obtained by yeast immobilized in new calcium alginatemaize stem ground tissue beads in comparison to calcium-alginate beads. A maximum ethanol concentration of $97.2 \mathrm{~g} / \mathrm{l}$, an ethanol yield per utilized sugar of $0.494 \mathrm{~g} / \mathrm{g}$, a percentage of the theoretical ethanol yield of $96.6 \%$, and a volumetric ethanol productivity of $2.03 \mathrm{~g} / \mathrm{lh}$ were obtained at the end of batch alcoholic fermentation of the medium based on sugar beet thick juice with an initial sugar concentration of $200 \mathrm{~g} / \mathrm{l}$.
\end{abstract}

Key words: bioethanol, alcoholic fermentation, immobilized yeast, Saccharomyces cerevisiae.

\section{REZIME}

Etanol proizveden alkoholnom fermentacijom iz obnovljivih sirovina, takozvani bioethanol ima široku primenu kao ekološki prihvatljiv i obnovljiv izvor energije, a takođe kao hemikalija i sirovina u medicini, u prehrambenoj industriji, industriji stočne hrane, farmaceutskoj i hemijskoj industriji. Gusti sok šećerne repe je pogodan supstrat za fermentaciju s obzirom na to da se može dugotrajno bezbedno skladištiti, što omogućuje proizvodnju bioetanola iz ove sirovine tokom cele godine. Primena gustog soka u poređenju sa tradicionalno korišćenom melasom ima više prednosti u vidu manjeg utroška energije za mešanje i kiselina za podešavanje $\mathrm{pH}$ vrednosti prilikom pripreme podloge za fermentaciju, višeg sadržaja nutrijenata za kvasac i manjih troškova prečišćavanja otpadni hvoda. U ovom radu je ispitana proizvodnja bioetanola iz gustog soka šećerne repe pomoću imobilisanih ćelija Saccharomyces cerevisiae u kuglicama kalcijum-alginata i u novom matriksu u formi kombinovanih kuglica od kalcijumalginata i samlevenog središnjeg dela stabla kukuruza. Više vrednosti parametara fermetnacije su ostvarene primenom kvasca imobilisanog na novom kombinovanom nosaču u poređenju sa kvascem u kuglicama kalcijum-alginata. Diskontinualnom alkoholnom fermentacijom pogloge na bazi gustog soka šećerne repe početne koncentracije šećera 200 g/l ostvarena je maksimalna koncentracija etanola od $97,2 \mathrm{~g} / \mathrm{l}$, prinos etanola po usvojenom šećeru $0,494 \mathrm{~g} / \mathrm{g}$, prinos u odnosu na teorijski 96,6\% $\mathrm{i}$ volumetrijska produktivnost etanola na kraju fermentacije od 2,03 $\mathrm{g} / \mathrm{lh}$.

Ključnereči: biotanol, alkoholna fermentacija, immobilisani kvasac, Saccharomyces cerevisiae.

\section{INTRODUCTION}

Modern ethanol production includes the technology of dynamic development due to a wide range of applications of its primary and secondary products. Ethanol produced by alcoholic fermentation from renewable green raw materials of biological origin is referred to as bioethanol (Sivakumar et al, 2010). Depending on the quality, ethanol is often classified as industrial-grade ethanol (used for medical purposes and chemical production), food-grade ethanol (used for human consumption) and fuel-grade ethanol, i.e. fuel-ethanol or denatured ethanol (used as an additive or substituent of fossil fuels). Sugar juices, starchy crops and lignocellulose materials are mostly used as raw materials in bioethanol production (Onuki et al, 2016). The processing of sugar beet into sugar and/or bioethanol in the same plant was proven to be a convenient option to meet the market demand and increase the profitability. Ethanol production from intermediate and by- products of sugar beet processing have a positive effect on the economic development (Krajnc and Glavić, 2009). Sugar beet thick juice is a convenient fermentation substrate due to its suitability for a long-term storage and the usability as a raw material in the ethanol production throughout the year. In comparison to traditionally used molasses, sugar beet thick juice provides benefits of the reduced usage of energy for mixing and acids for $\mathrm{pH}$ buffering in the fermentation medium preparation, increased levels of nutrients, and reduced waste water purification costs (Dodić et al., 2009). Furthermore, sugar beet thick juice provides a more favorable environment for yeast cells and is a more convenient substrate for ethanol fermentation by either free or calcium alginate entrapped yeast cells than molasses (Vučurović et al, 2019). The most common microorganism used in ethanol fermentation is the yeast Saccharomyces cerevisiae, which is used in suspended or immobilized forms. The yeast cell immobilization in ethanol fermentation offers many technical and economic advantages compared to the free cell system (Verbelen et al, 2006). The 
entrapment in calcium-alginate gel is one of the most commonly used techniques for the cell immobilization. We have previously found that the addition of maize stem ground tissue mill into calcium alginate for the preparation of a new immobilization matrix provides high surface areas for yeast cell attachment and biofilm growth, and increases alginate matrix porosity, enabling better mass transfer characteristics, better physical strength and stability of polymer beads in comparison to the Ca-alginate beads (Razmovski and Vučurović, 2009).

In the present study, the ethanol fermentation of sugar beet thick juice by Saccharomyces cerevisiae immobilized in a new combined matrix prepared by the addition of maize stem ground tissue mill into Ca-alginate was examined for the first time ever. This research is aiming to improve the productivity of ethanol by the application of mechanically stable biocatalyst with the improved mass transfer and physical strength for sugar beet thick juice fermentation as perspective raw material.

\section{MATERIAL AND METHOD}

Sugar beet thick juice was kindly provided by a domestic sugar plant in the Vojvodina province, the Republic of Serbia, and used as a fermentation substrate. The dry mass, total sugar, sucrose, total nitrogen, amino nitrogen and ash content of thick juice were estimated using the standard AOAC methods (AOAC, 2000).

Stems of the Gold Cup maize hybrid were collected from ready-to-harvest maize fields at the Budisava site, Vojvodina, Serbia. The outer fibrous tissue (epidermis) and nodes were manually removed from the ground tissue using a knife. The maize stem ground tissue was ground using the laboratory conical mill Miag-Braunschweig, type Doxy71b/4 (power 0.22 $\mathrm{kW}$ at $1375 \mathrm{rpm}$ ) to obtain particles less than $1 \mathrm{~mm}$ in diameter.

Saccharomyces cerevisiae in the form of instant bakery yeast (96,3\% dry mass) was suspended in the sterilized $0.9 \% \mathrm{NaCl}$ to form a basic cell suspension (6 g yeast dry mass per $100 \mathrm{~mL}$ ), which was used for the cells immobilization in Ca-alginate beads (AB). For the preparation of combined carriers (ABC), a total of $3 \mathrm{~g}$ of maize stem ground tissue mill was suspended into a 100 $\mathrm{mL} 0.9 \% \mathrm{NaCl}$ solution prior to sterilization and yeast addition. Na-alginate (Fluka Chemie AG, Switzerland) powder was dissolved in distilled water to form a solution (2\%). It was sterilized by autoclaving for $5 \mathrm{~min}$ at $121{ }^{\circ} \mathrm{C}$ and a pressure of 2.1 bar and stored overnight at $20^{\circ} \mathrm{C}$. The basic yeast suspension was mixed with the same volume of Na-alginate solution. For polymer beads formation, a $20 \mathrm{~mL}$ of cells-alginate mixture was transferred by dropping using a laboratory pipette with $3 \mathrm{~mm}$ diameter outlet, into $200 \mathrm{~mL}$ of a $0.1 \mathrm{~mol} / \mathrm{L} \mathrm{CaCl}_{2}$ solution, which was stirred continuously (magnetic stirrer, $150 \mathrm{rpm}$ ). Beads with immobilized yeast were left to harden in this solution with mild stirring for $15 \mathrm{~min}$. The diameter of $\mathrm{AB}$ beads was approximately $3 \mathrm{~mm}$, whereas the diameter of $\mathrm{ABC}$ beads was 5 $\mathrm{mm}$. In order to remove excess $\mathrm{Ca}^{2+}$ ions and non-entrapped cells, these beads were washed with sterile distilled water. The yeast immobilized in $A B$ and $A B C$ beads was used for the fermentation processes.

The fermentation medium was prepared by dissolving sugar beet thick juice with water to an initial sugar concentration of $200 \mathrm{~g} / \mathrm{L}$ without the supplementation of additional nutrients. The $\mathrm{pH}$ of the fermentation medium was adjusted to 5.0 with $10 \%$ sulfuric acid and sterilized by autoclaving at $121^{\circ} \mathrm{C}$ and a pressure of 2.1 bars for $20 \mathrm{~min}$. The inoculation was performed by transferring immobilized biocatalysts in beads of equal biomass concentration ( $0.6 \mathrm{~g}$ yeast dry mass) into a $200 \mathrm{~mL}$ of fermentation substrate in $500 \mathrm{~mL}$ Erlenmeyer flasks.
Fermentation experiments were carried out under anaerobic conditions in a thermostat at $30^{\circ} \mathrm{C}$ for $48 \mathrm{~h}$, at an agitation rate of $120 \mathrm{rpm}$ using a rotary shaker (GFL, type 3015, Germany).

The produced $\mathrm{CO}_{2}$ during fermentation was determined by measuring the weight loss of the fermentation system and the $\mathrm{CO}_{2}$ production rate $\left(\mathrm{dCO}_{2} / \mathrm{dt}\right)$ was calculated. At the end of each batch, the fermented medium was analyzed for ethanol and residual sugar concentration. The sample of fermentation medium was hydrolyzed in $33 \% \mathrm{HCl}$ at $100{ }^{\circ} \mathrm{C}$ during $10 \mathrm{~min}$ and neutralized with a $\mathrm{NaOH}$ solution, and sugars were than determined using the 3,5-dinitrosalicylic acid (Miller, 1959). The ethanol concentration was determined based on the density of the alcohol distillate at $20{ }^{\circ} \mathrm{C}$ using a picnometer (AOAC, 2000).

The ethanol productivity $(Q p, g / L ~ h)$ was calculated as the ratio of ethanol concentration in the fermented medium $(P, \mathrm{~g} / \mathrm{L})$ and the fermentation time $(t, \mathrm{~h})$, representing the average ethanol productivity during 1 hour of fermentation batch. The utilized sugar $(\mathrm{Su}, \mathrm{g} / \mathrm{L})$ was calculated as the difference between the initial ( $S o, g / L)$ and residual sugar concentrations $(S r, g / L)$ in the fermentation media. The sugar utilization (Ys, \%) was calculated as the mass content of utilized to the initial sugar. The ethanol yield ( $Y p / s, g / g)$ was calculated as the produced ethanol (g) per gram of the utilized sugar. The fermentation efficiency $(E p / s, \%)$ was represented as the percentage of the maximum theoretical ethanol yield.

All the experiments were conducted in triplicate and the mean data and standard deviation are presented. For the determination of significant differences among the mean values, the data obtained were analyzed statistically using ANOVA and Excel 2007 (at the p $<0.05$ significance level).

\section{RESULTS AND DISCUSSION}

Cells of $S$. cerevisiae immobilized in Ca-alginate beads (AB) and combined beads made of Ca-alginate with the addition of grinded maize stem ground tissue (ABC) were used for sugar beet thick juice fermentation. The results of the thick juice performed were as follows (\% w/w): 68.22 dry mass, 58.8 total sugars, 57.7 sucrose, 1.22 total nitrogen, 0.3 amino nitrogen and 2.1 ashes.

The mass of $\mathrm{CO}_{2}$ produced and the $\mathrm{CO}_{2}$ production rate $\left(\mathrm{dCO}_{2} / \mathrm{dt}\right)$ were measured throughout the fermentation process in order to examine the fermentation kinetics (Fig 1a and Fig 1b, respectively) The $\mathrm{CO}_{2}$ production time periods (Fig 1a) show that fermentation was significantly faster in the system with yeast immobilized in the $\mathrm{ABC}$ carrier in comparison to $\mathrm{AB}$, indicating a more efficient mass transfer through the immobilization carrier prepared with the addition of grinded maize stem ground tissue. The time to complete the fermentation at $30^{\circ} \mathrm{C}$ with the immobilized yeast on both $\mathrm{AB}$ and $\mathrm{ABC}$ was 48 h. The mechanical stability of Ca-alginate beads during fermentation is highly dependent on the $\mathrm{CO}_{2}$ development. The stepped shape of the time course of $\mathrm{CO}_{2}$ production in the $\mathrm{AB}$ system is particularly pronounced in the period from 24 to $36 \mathrm{~h}$ of fermentation, which was in accordance with the bursting of the Ca-alginate beads. Conversely, when the ABC carrier was used, beads were physically stable owing to the highly porous structure of maize stem ground tissue. Consequently, no fissures formations on beads or substrate and product diffusion restrictions were noticed. The results of $\mathrm{CO}_{2}$ production rate presented in Fig.1b demonstrate that $\mathrm{dCO}_{2} / \mathrm{dt}$ was by far higher in the $\mathrm{ABC}$ fermentation system than in the $\mathrm{AB}$ system especially at the beginning of fermentation. The maximum $\mathrm{CO}_{2}$ production rates of $5.49 \mathrm{~g} / \mathrm{Lh}$ and $2.41 \mathrm{~g} / \mathrm{Lh}$ were obtained after $6 \mathrm{~h}$ and $36 \mathrm{~h}$ in the $\mathrm{ABC}$ and $\mathrm{AB}$ system fermentations, respectively. 


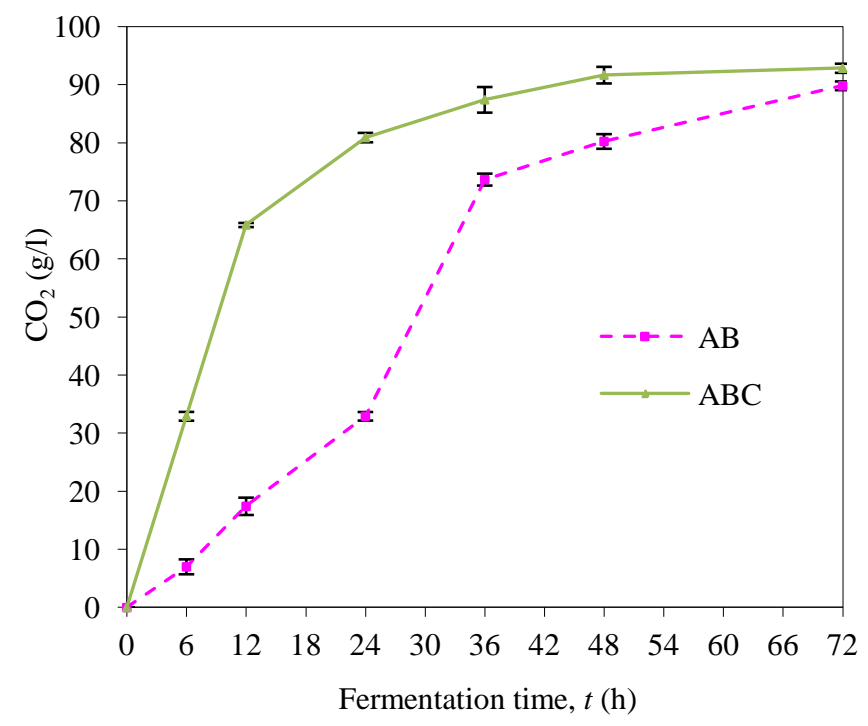

a)

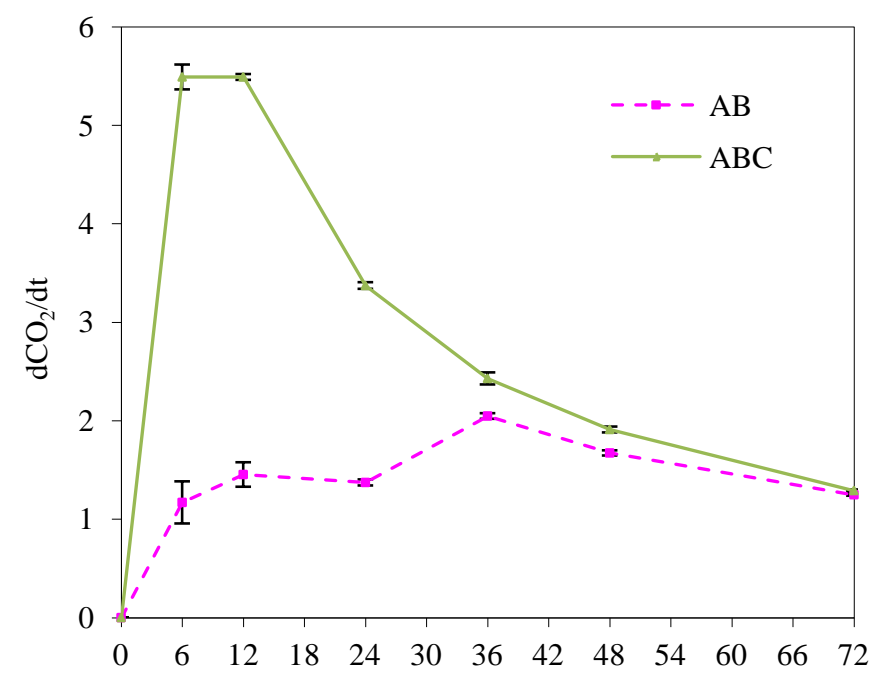

Fermentation time, $t(\mathrm{~h})$

b)

Fig. 1 a) $\mathrm{CO}_{2}$ production and b) $\mathrm{CO}_{2}$ production rate $\left(\mathrm{dCO}_{2} / \mathrm{dt}\right)$ during thick juice fermentation by Saccharomyces cerevisiae immobilized in Ca-alginate beads (AB), and Ca-beads with the addition of grinded maize stem ground tissue $(A B C)$

Residual sugar and ethanol concentrations in the fermented media were determined at the end of the fermentation batch, whereas sugar utilization, ethanol concentration, ethanol productivity and ethanol yield were calculated accordingly (Table 1).

Table 1. Parameters of sugar beet thick juice fermentation by Saccharomyces cerevisiae immobilized in Ca-alginate beads $(A B)$, and Ca-beads with the addition of grinded maize stem ground tissue $(A B C)$

\begin{tabular}{||c|c|c||}
\hline \hline Immobilization carrier & $\mathrm{AB}$ & $\mathrm{ABC}$ \\
\hline Sugar utilization $Y s(\%)$ & $98.0 \pm 0.01$ & $98.4 \pm 0.07$ \\
\hline Ethanol concentration $P(\mathrm{~g} / \mathrm{l})$ & $95.2 \pm 0.4$ & $97.2 \pm 1.5$ \\
\hline Ethanol productivity $Q p(\mathrm{~g} / \mathrm{lh})$ & $1.98 \pm 0.01$ & $2.03 \pm 0.03$ \\
\hline Ethanol yield $Y p / s(\mathrm{~g} / \mathrm{g})$ & $0.486 \pm 0.002$ & $0.494 \pm 0.008$ \\
\hline Fermentation efficiency $\mathrm{E} / \mathrm{s}(\%)$ & $95.0 \pm 0.4$ & $96.6 \pm 1.6$ \\
\hline
\end{tabular}

After $48 \mathrm{~h}$ of fermentation, almost the entire sugar present was utilized by the immobilized yeast in $\mathrm{AB}(98 \%)$ and $\mathrm{ABC}$ (98.4 \%). The yeast immobilized in ABC accomplished a slightly higher ethanol concentration $(97.2 \mathrm{~g} / \mathrm{L})$ than in the yeast immobilized in AB $(9.2 \mathrm{~g} / \mathrm{L})$. The average ethanol productivity per hour (over the course of $48 \mathrm{~h}$ ) reached maximum values of $1.98 \mathrm{~g} / \mathrm{Lh}$ and $2.03 \mathrm{~g} / \mathrm{Lh}$ in the yeast immobilized in $\mathrm{AB}$ and $\mathrm{ABC}$, respectively. Ethanol yields per utilized sugar were also higher for the yeast immobilized in ABC $(0.494 \mathrm{~g} / \mathrm{g})$ than in $\mathrm{AB}$ $(0.486 \mathrm{~g} / \mathrm{g})$, suggesting that utilized sugar was more efficiently used for ethanol production in the system with the yeast immobilized in ABC. Consequently, high fermentation efficiencies of $95 \%$ and $96.6 \%$ were obtained in the yeast immobilized in $\mathrm{AB}$ and $\mathrm{ABC}$, respectively. The results obtained indicate that the yeast immobilized in $\mathrm{ABC}$ showed better fermentative performances relative to sugar utilization, ethanol productivity, ethanol yield per utilized sugar and ethanol fermentation efficiency than the yeast immobilized in AB.

\section{CONCLUSION}

Efficient ethanol production from sugar beet thick juice has been accomplished by both immobilization systems examined. However, the immobilization of yeast using the combined carrier (ABC) prepared by the addition of ground maize stem ground tissue into Ca-alginate enabled a faster substrate and product mass transfer through Ca-alginate and consequently improved the fermentation process. On balance, the fermentation procedures carried out with the yeast immobilized in $A B C$ resulted in a slightly higher sugar utilization ability, higher ethanol fermentation performances, much better mass transfer characteristics and improved mechanical stability in comparison to the yeast immobilized in AB.

ACKNOWLEDGMENT: This paper is part of the research within the project TR-31002 "Improving the production of bioethanol from sugar beet processing products" financed by the Ministry of Education, Science and Technological Development of the Republic of Serbia. The financial support is highly acknowledged and appreciated.

\section{REFERENCES}

Onuki., S.,Koziel, J. A., Jenks W. S., Grewell, D.,Cai, L.,van Leeuwen, J. H., (2016)Taking ethanol quality beyond fuel grade: A review. Journal of the Institute of Brewing, 122(4), 588-598.

Krajnc, D., Glavič, P. (2009). Assesment of different strategies for the co-production of bioethanol and beet sugar. ChemicalEngineering Research and Design, 87 (9), 1217-31.

Dodić, S. N., Popov, S. D., Dodić, J.M., Ranković, J.A., Zavargo, Z.Z. (2009),Bioethanol production from thick juice as intermediate of sugar beet processing. Biomass andBioengineering,33 (5), 822-7.

Razmovski, R., Vučurović, V. (2011), Ethanol production from sugar beet molasses by $S$. cerevisiae entrapped in an alginate-maize stem ground tissue matrix. Enzyme and Microbial Technology, 48 (11), 378-385.

Vučurović, V., Puškaš, V., Miljić, U., (2019) Bioethanol production from sugar beet molasses and thick juice by free and immobilized Saccharomyces cerevisiae. Journal of Brewing and Distilling, 125, 134-142.

Received: 04. 04. 2019.

Accepted: 28. 11. 2019. 